\title{
Chemical compositions and hypoglycemic activities of the protein and mucilage of Casimiroa edulis (Llave \& Lex) seeds and fruits
}

\author{
Nabawyea Ibrahim ${ }^{1}$, Seham El Hawary ${ }^{2}$, Magdy Mohammed ${ }^{1}$, Sanaa Ali ${ }^{1}$, Zeinab Kandil ${ }^{2}$, Esraa Refaat ${ }^{*}$ \\ ${ }^{1}$ National Research Centre, Giza, Egypt. \\ ${ }^{2}$ Faculty of Pharmacy, Cairo University, Cairo, Egypt.
}

\section{ARTICLE INFO \\ Received on: 14/06/2019 \\ Accepted on: 17/08/2019 \\ Available online:05/10/2019}

\section{Key words:}

ALP, Casimiroa edulis, histopathological, mucilage, protein, streptozotocin.

\begin{abstract}
During the present study, chemical compositions of the protein and mucilage of seeds and fruits of Casimiroa edulis (Llave \& Lex) as well as their hypoglycemic effects and other related biochemical parameters were studied for the first time. The protein content of $C$. edulis seeds was prepared with $4 \%(\mathrm{w} / \mathrm{w})$ yield. The amino acid analyzer of protein hydrolysates led to the identification of 17 amino acids. Glutamic acid (10.25\%) was considered the major amino acid. Moreover, the mucilage content of $C$. edulis fruits was prepared with $11 \%(\mathrm{w} / \mathrm{w})$ yield. GLC analysis of mucilage hydrolysates revealed the identification of ten sugars represented (87.19\%), with galacturonic acid (31.23\%) as the main component. Significant hypoglycemic effects of protein and mucilage were recorded with respect to control and glibenclamide (standard drug). In addition, histopathological examination was performed, and the results showed that treatment with protein and mucilage remarkably improved Alanine Aminotransferase, Aspartate Aminotransferase, and Alkaline Phosphatase activities after streptozotocin induction with respect to control, also ameliorated the disturbances in Gamma Glutamyl Transferase, total protein \& albumin, Glutathione levels, Catalase and lipid peroxidation activities. The prepared protein and mucilage exhibited properties that recommend them as natural supplements or in food industries for improving human being health.
\end{abstract}

\section{INTRODUCTION}

Casimiroa edulis belongs to family Rutaceae and it is widely distributed in Mexico and Central America (Landaverde et al., 2009). C. edulis is an evergreen tree that reaches up to 18 $\mathrm{m}$ tall and it is of economically high importance as it produces an edible fruit known as white Sapote (Ya-Ming et al., 2011), the plant under study previously reported to be used as sedative, hypnotic, anticonvulsant, and antihypertensive and also used for dermatological cases. Alkaloids, coumarins, limonoids, and flavonoids, i.e., zapotin and 3, 5-trimethoxy flavones, were previously reported (Awaad et al., 2011). Hyperglycemia is a chronic diabetic disease that led to the oxidative stress which was observed particularly in the liver that has a major and

\section{${ }^{*}$ Corresponding Author}

Esraa Refaat, National Research Centre, Giza, Egypt. E-mail: esraa.refaat84@gmail.com critical role in the regulation of carbohydrate metabolism (Uyar et al., 2017).

The present study aimed to investigate the hypoglycemic effect of seeds protein and fruits mucilage of $C$. edulis accompanied with other biochemical parameters including blood glucose level, total protein content, total albumin, liver functions [Alanine Aminotransferase (ALT), Aspartate Aminotransferase (AST), Alkaline Phosphatase (ALP), and Gamma Glutamyl Transferase (GGT)], and the antioxidant activity, as well as studying the chemical composition of the prepared protein and mucilage hydrolysates responsible for this activity.

\section{MATERIALS AND METHODS}

\section{Plant material}

Casimiroa edulis (seeds and fresh fruits) were collected from El-Zohrya botanical garden, Giza, Egypt in April 2015 and the taxonomical identification was provided by Mrs. Threase Labib, plant taxonomy consultant at the Ministry of Agriculture and former director of El-Orman botanical garden (voucher No. 31-3-2015I). 


\section{Investigation of protein contents of $\mathrm{C}$. edulis seeds}

The defatted dried powdered seeds $(200 \mathrm{~g})$ were stirred in $10 \%$ sodium chloride solution (Three times, $100 \mathrm{ml}$ each) and then filtered. 10\% trichloroacetic acid (TCA) equal volume solution was added to the filtrate to precipitate the protein as a white flocculent amorphous precipitate and the experiment was proceeded as reported by Aly et al. (2016). The previously prepared protein $(10 \mathrm{mg})$ was hydrolyzed and the amino acid of the protein hydrolysate was investigated as previously mentioned conditions (Aly et al., 2016). The results were reported in Table 1.

\section{Electrophoresis of protein}

Polyacrylamide gel electrophoresis of the previously prepared protein was performed according to the methods described by Darwesh et al. (2015).

\section{Preparation of staining solution}

$0.1 \mathrm{~g}$ coomassie brilliant blue powder, $10 \mathrm{ml}$ of glacial acetic acid, $40 \mathrm{ml}$ of ethanol then completed by distilled water to $100 \mathrm{ml}$ and the solution was stirred for 1 hour then filtered through Whatman No. 1 paper. Relative mobility $\left(R_{\mathrm{f}}\right)$ and band percent $(B \%)$ of the electrophoretically separated proteins beside molecular weights (Mwts) were determined with respect to marker peptide of standard molecular weights ranging from 6.458 to $195.755 \mathrm{KDa}$ then the polyacrylamide gel plates were photographed (Fig. 1) according to methodology reported previously by El-Sayed et al. (2018).

\section{Investigation of polysaccharide contents in C. edulis fruits}

\section{Cold extraction of mucilage (C. E. M.)}

The mucilage was prepared by using 500 g powdered plant of $C$. edulis fruits and the sugar of the mucilage hydrolysate was derivatized and analyzed by GLC using the conditions as previously reported (Ibrahim et al., 2016).

\section{Material for in-vivo hypoglycemic studies}

\section{Chemicals and biochemical kits}

Kits used for the quantitative determination of different parameters were purchased from Bio-diagnostic. Streptozotocin (STZ) (Sigma Co.) for diabetes induction and glibenclamide (Daonil) ${ }^{\circledR}$ (Sanofi Aventis) were used as a standard drug.

Table 1. Amino acid analysis of protein hydrolysate of Casimiroa edulis seeds.

\begin{tabular}{lclc}
\hline Amino acid & Percentage & Amino acid & Percentage \\
\hline 1-Aspartic & 5.86 & 10-Tyrosine & 2.15 \\
2-Therionine & 1.97 & 11-Phenylalanine & 2.94 \\
3-Serine & 2.21 & 12-Histidine & 1.39 \\
4-Glutamic * & 10.25 & 13-Lysine & 1.92 \\
5-Glycine & 2.57 & 14-Argnine & 3.89 \\
6-Alanine & 2.29 & 15-Proline & 2.01 \\
7-Valine & 3.98 & 16-Cystine & 1.00 \\
8-Isoleucine & 2.28 & 17-Methionine & 0.35 \\
9-Leucine & 4.05 & & \\
\hline
\end{tabular}

*Refers to the main component (Glutamic) in the protein hydrolysate of C. edulis seeds.

\section{Animals and animal rights}

Animal house of National Research Centre has provided male Wister Albino rats (150-170 g) for the experimental study, which were kept to accommodate on laboratory conditions for 2 weeks and were given food and water during the whole period of the experiment under constant environmental and nutritional conditions. Approvement of the anesthetic procedures complied with the legal ethical guidelines was approved by both the Ethical Committee of the Federal Legislation and National Institutes of Health Guidelines in USA and the ethical committee of the National Research Centre in Egypt with registration No. (15-028).

\section{Doses and route of administration}

\section{Induction of diabetes}

Intraperitoneal injection of the animals with STZ was done to induce diabetes (Uyar et al., 2017). Blood glucose level was measured after 72 hours by using glucometer after 1, 2, 3, and 4 week's intervals.

\section{Experimental design}

In the present study, 30 animals were divided into five groups and each group consists of six rats where:

- Group 1 is the normal healthy control group.

- Group 2 (+ control), induction of diabetes by (IP) injection (45 mg/kg body weight STZ dissolved in $0.01 \mathrm{M}$ citrate buffer immediately before use). After injection, 5\% glucose solution was orally administered. After 72 hours, fasting blood samples were collected and fasting blood glucose was measured $(>600$ $\mathrm{mg} / \mathrm{dl})$.

- Group 3 diabetic rats orally treated with the mucilage of $C$. edulis fruits $(500 \mathrm{mg} / \mathrm{kg})$.

- Groups 4 diabetic rats orally treated with the protein of C. edulis seeds $(500 \mathrm{mg} / \mathrm{kg})$.

- Group 5 diabetic animals treated with $10 \mathrm{mg} / \mathrm{kg}$ body weight glibenclamide as standard drug.

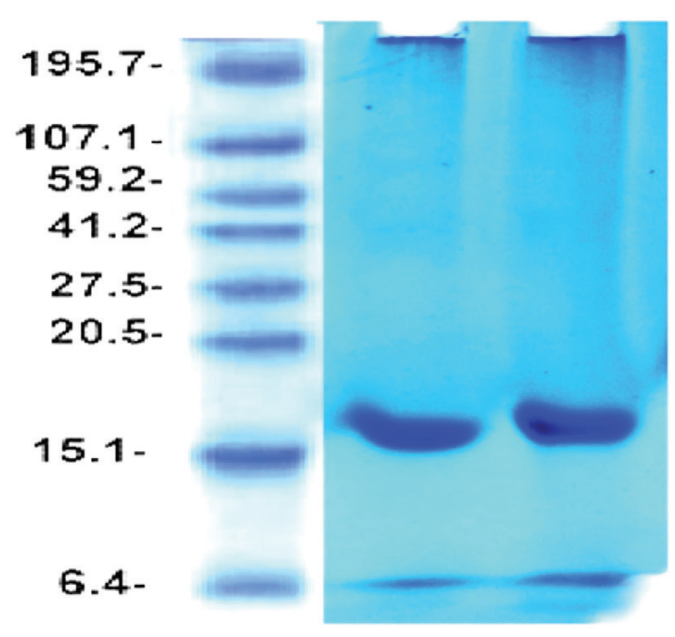

Figure 1. Electrophoretic pattern of the protein of Casimiroa edulis seeds. Lane 1: Marker \& Lane 2: protein of Casimiroa edulis seeds. 


\section{Biochemical assays}

Sample preparations

After 30 days of treatments, blood was collected from overnight fasted animals (12-14 hrs) from sublingual vein, left to clot then centrifuged at $3,000 \mathrm{r} /$ minute at $4^{\circ} \mathrm{C}$ and the separated serum was stored at $80^{\circ} \mathrm{C}$ for further determinations of liver functions.

\section{Parameters measured}

Liver functions enzymes in serum: Total protein content, albumin level, ALT and AST and ALP as reported previously by Mohammed et al. (2018), (GGT) (Hyder et al., 2013). Antioxidant parameters: Lipid peroxide, glutathione concentration (GSH) and catalase as reported by Sadek et al. (2016) previously. Calculation percentages of change and improvement were calculated according to Ibrahim et al. (2016). Analysis of variance (ANOVA) test was used in statistical analysis.

\section{Histological study}

Sections from liver and pancreas were fixed in $10 \%$ buffered neutral formalin and histopathological procedures were performed according to Ali et al. (2019).

\section{RESULTS AND DISCUSSION}

\section{Protein and mucilage composition}

In the present study, the protein of $C$. edulis seeds (4\%). 17 Amino acids were identified; Glutamic 10.25\% which represented the major amino acid, Aspartic acid (5.86\%), Leucine 4.05\%, Valine 3.98\%, Arginine 3.89\%, Phenylalanine $2.94 \%$, Glycine $2.57 \%$, Alanine 2.29\%, Isoleucine 2.28\%, Serine $2.21 \%$, Tyrosine $2.15 \%$, Proline $2.01 \%$, Therionine $1.97 \%$, Lysine $1.92 \%$, Histidine $1.39 \%$, Cystine $1 \%$, and Methionine $(0.35 \%)$ as shown in Table 1. Protein was represented electrophoretically by two bands identified at relative mobility 0.683 and 0.937 (Molecular weights 16.009 and $6.480 \mathrm{KDa}$ ) in comparison with a marker. It was noticed that the first band $\left(R_{f} 0.683\right.$; Mwt 16.009 ; B\% 57.4\%) considered the major band as shown in Figure 1.
Mucilage of $C$. edulis was prepared as mentioned above. The yield by the cold method gave (56 g) $11.2 \%(\mathrm{w} / \mathrm{w})$ but no yield by the hot method. The isolated mucilage was pale gray in color and it gave positive Molische's test. Acid hydrolysis of the mucilage was done as mentioned above. GLC analysis of the mucilage hydrolysate, as shown in Figure 2 and Table 2, revealed the identification of ten sugar moieties which represented $87.19 \%$ of the total sugar hydrolysate, the main sugar identified is galacturonic acid (31.23\%) arabinose (13.57\%), galactose $(10.17 \%)$, glucuronic acid $(9.74 \%)$, glucose $(6.82 \%)$, sorbitol $(6.04 \%)$, mannitol $(1.67 \%)$, and mannose \& xylose $(1.27 \%$ and $1.047 \%)$.

\section{Hypoglycemic assay}

The results demonstrated the use of protein and mucilage of C. edulis seeds and fruits $(500 \mathrm{mg} / \mathrm{kg}$ ) for the study of antidiabetic activity against the standard drug glibenclamide $(10 \mathrm{mg} /$ $\mathrm{kg}$ ). Protein remarkably decreases the blood glucose level which increased between 500 and $600 \mathrm{mg} / \mathrm{dl}$ after STZ induction. After the $1 \mathrm{st}$ week of protein seeds treatment, there was a reduction in blood glucose level to $403.47 \mathrm{mg} / \mathrm{dl}$, and on $2 \mathrm{nd}$ week, the reduction reached $247.42 \mathrm{mg} / \mathrm{dl}$, while highly significant results $(141.56 \mathrm{mg} / \mathrm{dl}$ and $117.28 \mathrm{mg} / \mathrm{dl})$ were recorded after 3 to 4 weeks of treatment in comparison to control $(476.72 \mathrm{mg} / \mathrm{dl}$ and $273.80 \mathrm{mg} / \mathrm{dl})$ and standard drug-treated groups $(163.32 \mathrm{mg} / \mathrm{dl}$ and $107.15 \mathrm{mg} / \mathrm{dl}$ )as shown in Table 3.

Mucilage remarkably decreases the blood glucose level which increased between 500 and $600 \mathrm{mg} / \mathrm{dl}$ after STZ induction. Significant reduction of the blood glucose level in group treated with mucilage after 1 to 2 weeks, $414.94 \mathrm{mg} / \mathrm{dl}$ and $236.73 \mathrm{mg} /$ dl while highly significant results recorded after 3 to 4 weeks of treatment, $125.41 \mathrm{mg} / \mathrm{dl}$ and $107.37 \mathrm{mg} / \mathrm{dl}$ in comparison to control (476.72 mg/dl and $273.80 \mathrm{mg} / \mathrm{dl}$ ) and standard drug-treated groups (163.32 mg/dl and $107.15 \mathrm{mg} / \mathrm{dl}$ ) as shown in Table 3.

\section{Effect on hepatic liver enzymes}

STZ induction led to the increase in the ALP, AST, and ALT by $146.79 \%, 63 \%$, and $37 \%$, respectively, with respect to

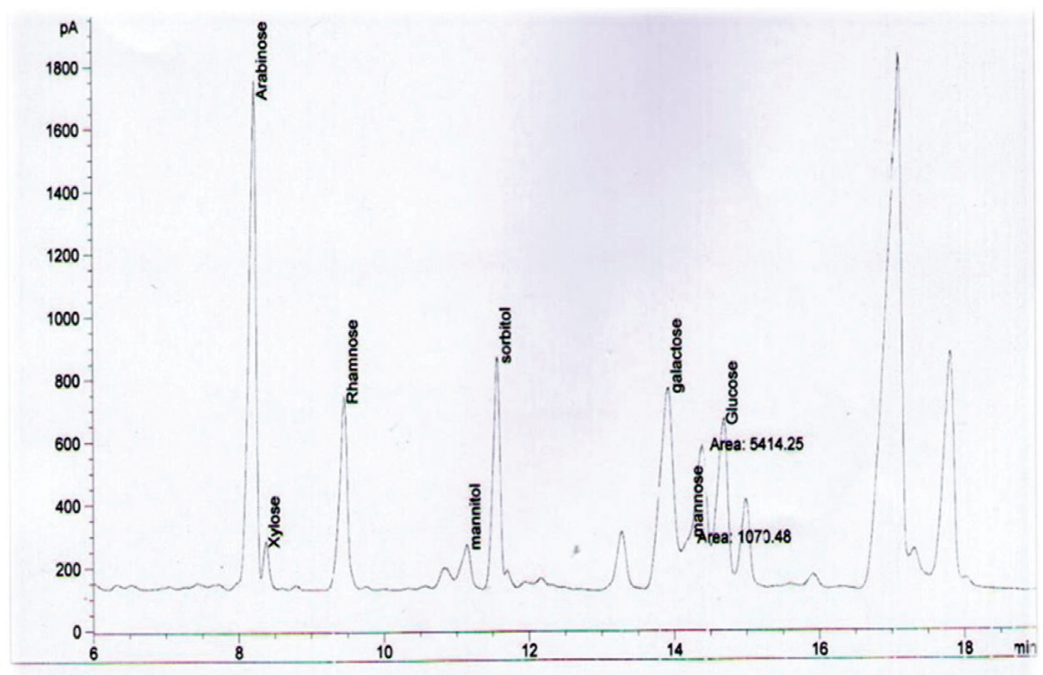

Figure 2. GLC chromatogram of mucilage hydrolysates of Casimiroa edulis fruits. 
Table 2. GLC analysis of the mucilage hydrolysate of Casimiroa edulis (Llave \& Lex) fruits.

\begin{tabular}{cccl}
\hline Peak number & Retention time & Area \% & Name \\
\hline 1 & 8.229 & 13.57 & Arabinose \\
2 & 8.378 & 1.047 & Xylose \\
3 & 9.461 & 5.62 & Rhamnose \\
4 & 10.480 & 0.91 & unknown \\
5 & 11.145 & 1.68 & Mannitol \\
6 & 11.572 & 6.04 & Sorbitol \\
7 & 13.282 & 2.17 & unknown \\
8 & 13.925 & 10.17 & Galactose \\
9 & 14.211 & 1.27 & Mannose \\
10 & 14.392 & 6.42 & Unknown \\
11 & 14.693 & 6.82 & Glucose \\
12 & 14.993 & 3.29 & Unknown \\
13 & 17.115 & 31.23 & * Galacturonic acid \\
14 & 17.819 & 9.74 & Glucuronic acid \\
\hline
\end{tabular}

Total identified sugar represented : $87.19 \%$

*Refers to the main component (Galacturonic acid) in the mucilage hydrolysate of C. edulis fruits.

control due to hepatic cellular damage (Ahmed et al., 2015). Group treated with protein of $C$. edulis seeds improved liver enzymes by $65 \%,-1.79 \%$ and $21.88 \%$, respectively, and group treated with mucilage of $C$. edulis fruits enhanced the hepatic marker enzymes by $69.08 \%, 15.36 \%$, and $17.49 \%$, respectively, with respect to group treated with glibenclamide $(40.04 \%, 10.59 \%$, and $20.01 \%)$ in comparison with control untreated as supported by Table 4.

\section{Antioxidative properties}

The administration of STZ significantly increased the lipid peroxidation by $79.008 \%$ and also led to catalase activity reduction by $-31.81 \%$ in the diabetic group comparing to control. Lipid peroxidation was remarkably decreased in the protein and mucilage treated groups by $26.45 \%$ and $4.87 \%$, also the standard drug-treated group improved the lipid peroxidation by $9.91 \%$ comparing to the control group. Moreover, it was observed that both protein and mucilage have promising effects in the Catalase (CAT) activities of the diabetic rats by $-19 \%$ and $-13.13 \%$, and on the other hand, glibenclamide can improve the catalase activity by $-10.20 \%$ compared to control (Table 5).

Elevation of hepatic GSH level was shown in both the protein and mucilage treated groups by $-6.58 \%$ and $-15.91 \%$, indicating that they can elevate the biosynthesis of GSH or decrease the oxidative stress resulting in reducing GSH degradation, or possess both effects, furthermore using glibenclamide as a standard drug for treatment may improve the GSH by $2.47 \%$ comparing to control as STZ-induced diabetic rats resulted in decreasing the hepatic GSH levels $(-41.80 \%)$ with respect to normal rats as shown in Table 5. The previously mentioned agreed with Abd El-Fattah et al. (2018) and Ahmed et al. (2015). These results suggested that both mucilage and protein may have antioxidant activity, reducing free radicals and improving hepatic antioxidant enzymes.

\section{Effect on total protein, GGT, and albumin}

In case of STZ diabetic rats, reduction in albumin and total protein $(-19.62 \%$ and $-38.46 \%)$ were reported compared to control group due to hepatic metabolic disturbances in STZinduced rats as stated previously by Ali et al. (2011), and increase in serum GGT by $91.34 \%$. From Table 6, we concluded that treatments with the protein and mucilage of $C$. edulis in comparison with glibenclamide drug ameliorated these disturbances by different percentages as follows: slight elevations in groups treated with protein and mucilage in which albumin records $-3.63 \%$ and $-9.52 \%$, while group treated with glibenclamide by $-8.23 \%$ comparing to control. In case of total protein results, there was a significant amelioration with percentages $-18.52 \%$ and $-21.64 \%$, in case of protein and mucilage treated groups while glibenclamide records $-11.37 \%$ with respect to control group. According to GGT, slight reduction in protein, mucilage treated groups in comparison to glibenclamide with respect to control by $64.86 \%, 48.49 \%$, and $68.31 \%$, respectively, as shown in Table 6 . Treatment with protein and mucilage of $C$. edulis seeds and fruits ameliorated the disturbances in GGT, total protein, and albumin as a result of STZ induction.

\section{Effect on liver and body weights}

Table 7 showed changes in liver and bodyweights and relative liver body weight in STZ-induced group, a slight decrease in liver weight by $90 \mathrm{~g}$ and body weight by $82 \mathrm{~g}$ while relative liver/body weights were $106 \mathrm{~g}$ compared to control was reported concurred with Ali et al. (2011) whom stated that the decrease in body weight and total hepatic protein related to liver metabolic disturbance was due to diabetes. Treatment with protein seeds and mucilage fruits improved liver weight by $112 \mathrm{~g}$ and $121 \mathrm{~g}$ and body weight by $93 \mathrm{~g}$ and $99 \mathrm{~g}$ comparing to glibenclamide $(129 \mathrm{~g})$; this led to relative liver/body weights of $117 \mathrm{~g}$ and $121 \mathrm{~g}$ for protein seeds and mucilage fruits comparing to glibenclamide (128 g).

\section{Histopathological assay}

The normal histopathological study of the liver was observed in the control group (Fig. 3A and B) Parenchyma and hydropic degeneration in hepatocytes and necrosis were observed in liver sections of the diabetic group. Severe fibrosis and inflammatory cell infiltration were detected in central and portal areas. Fig. 3D and $\mathrm{C}$ shows that in the protein and mucilage treated groups, the liver of diabetic rats was reduced as well as degeneration and necrosis was observed locally in hepatocytes comparing to the control. Figure $3 \mathrm{E}$ showed nearly normal histological structure in the group treated with glibenclamide.

The normal histopathological study of pancreas revealed normal pancreatic cells (Fig. 4A), while Figure 4B showed basic lesions in Langerhans islets of pancreas; reduction in islets of Langerhans numbers and their cellular content, also the necrosis and lymphocyte infiltration of some islets, were noticed in diabetic groups in agreement with Taie et al. (2015). In treated protein and mucilage groups, these findings were reduced (Fig. 4D and C) compared to control. Figure 4E showed normal histological structures of islets of Langerhans in the group treated with glibenclamide.

Hyperglycemia decreases the insulin level leading to initiating beta-oxidation of fatty acids through increasing the activity of fatty acyl Coenzyme-A (oxidase enzyme) resulting in peroxidation of cell membrane main components (lipid or protein), which impairs membrane functions by changing the activity of 
Table 3. Effect of protein and mucilage of Casimiroa edulis seeds and fruits on blood glucose level in normal and diabetic rats in comparison with glibenclamide (standard).

\begin{tabular}{lcccc}
\hline Duration & Positive control & Mucilage (fruits) & Protein (seeds) & Standard \\
\hline Control $(\mathrm{mg} / \mathrm{dl})$ & $99.833 \pm 7.35$ & $101.66 \pm 6.0$ & $103.6 \pm 5.4$ & $92.33 \pm 5.11$ \\
72 hrs $(\mathrm{mg} / \mathrm{dl})$ & $579.6 \pm 29.6$ & $545.3 .5 \pm 15.9$ & $477.8 \pm 12.3$ & $477.8 \pm 12.3$ \\
$\%$ of change & +480.57 & +436.44 & +361.2 & +417.49 \\
1 week $(\mathrm{mg} / \mathrm{dl})$ & $569.5 \pm 19.5$ & $421.83 \pm 13.52$ & $418.17 \pm 18.8$ & $440.16 \pm 20.3$ \\
\% of change & +470.45 & +314.94 & +303.47 & +376.72 \\
2 weeks $(\mathrm{mg} / \mathrm{dl})$ & $446.5 \pm 13.9$ & $240.66 \pm 13.6$ & $256.33 \pm 13.3$ & $252.8 \pm 15.3$ \\
\% of change & +347.24 & +136.73 & $146.66 \pm 8.3$ & +173.8 \\
3 weeks $(\mathrm{mg} / \mathrm{dl})$ & $421.66 \pm 18.11$ & $127.5 \pm 6.4$ & +41.56 & $150.8 \pm 9.3$ \\
\% of change & +322.37 & +25.41 & $121.5 \pm 5.3$ & +63.32 \\
4 weeks $(\mathrm{mg} / \mathrm{dl})$ & $417.8 \pm 12.3$ & $109.16 \pm 7.1$ & +17.28 & $108.16 \pm 6.3$ \\
\% of change & +318.49 & +7.37 & & +7.15 \\
\hline
\end{tabular}

Data are means \pm SD of six rats in each group, Blood glucose level expressed as $\mathrm{mg} / \mathrm{dl}$.

Table 4. Effect of protein and mucilage of Casimiroa edulis seeds and fruits on serum blood ALP, AST, and ALT in normal and diabetic rats in comparison with glibenclamide.

\begin{tabular}{|c|c|c|c|c|c|c|}
\hline \multirow{2}{*}{ Parameters } & \multirow{2}{*}{$\begin{array}{c}\text { Control } \\
\text { G1 }\end{array}$} & Diabetes & Mucilage (fruits) & Protein (seeds) & Standard & \multirow{2}{*}{ ANOVA } \\
\hline & & G2 & G3 & G4 & G5 & \\
\hline $\begin{array}{l}\text { ALP (U/l) } \\
\% \text { of change }\end{array}$ & $28.17 \pm 1.66^{\mathrm{e}}$ & $\begin{array}{c}69.52 \pm 2.02^{\mathrm{a}} \\
+\mathbf{1 4 6 . 7 9}\end{array}$ & $\begin{array}{l}47.77 \pm 3.38^{\mathrm{b}} \\
\quad+\mathbf{6 9 . 5 8}\end{array}$ & $\begin{array}{c}46.48 \pm 1.05^{\mathrm{b}} \\
+\mathbf{6 4 . 9 9}\end{array}$ & $\begin{array}{c}39.45 \pm 2.70^{\mathrm{d}} \\
+\mathbf{4 0 . 0 4}\end{array}$ & 0.0001 \\
\hline $\begin{array}{l}\mathrm{AST}(\mathrm{U} / 1) \\
\% \text { of change }\end{array}$ & $36.92 \pm 2.89^{c}$ & $\begin{array}{c}60.46 \pm 1.67^{\mathrm{a}} \\
\quad+\mathbf{6 3 . 7 6}\end{array}$ & $\begin{array}{c}42.59 \pm 2.75^{b} \\
\quad+\mathbf{1 5 . 3 6}\end{array}$ & $\begin{array}{c}36.26 \pm 4.52^{\mathrm{c}} \\
\mathbf{- 1 . 7 8}\end{array}$ & $\begin{array}{c}40.83 \pm 2.94^{\mathrm{b}} \\
\quad+\mathbf{1 0 . 5 9}\end{array}$ & 0.0001 \\
\hline $\begin{array}{l}\text { ALT (U/l) } \\
\% \text { of change }\end{array}$ & $24.59 \pm 2.65^{\mathrm{c}}$ & $\begin{array}{c}33.71 \pm 2.12^{\mathrm{a}} \\
+\mathbf{3 7 . 0 9}\end{array}$ & $\begin{array}{c}28.89 \pm 3.40^{b} \\
+17.49\end{array}$ & $\begin{array}{l}29.97 \pm 4.01^{\mathrm{b}} \\
\quad+\mathbf{2 1 . 8 8}\end{array}$ & $\begin{array}{c}29.51 \pm 2.07^{b} \\
+\mathbf{2 0}\end{array}$ & 0.0001 \\
\hline
\end{tabular}

Data are expressed as means \pm SD of six rats in each group.

Values of AST, ALT, and ALP are expressed as U/L.

$p$ is the level of significance, where $\mathrm{p}<0.05$ is significant. ANOVA $\mathrm{p}<.0001$.

Analysis of data is carried out by one way (ANOVA) accompanied by post hoc (least significant difference [LSD]) (SPSS computer program).

Table 5. Effect of protein and mucilage of Casimiroa edulis seeds and fruits on oxidative parameters (Lipid peroxide, catalase, and glutathione) in normal and diabetic rats in comparison with glibenclamide.

\begin{tabular}{|c|c|c|c|c|c|c|}
\hline \multirow{2}{*}{ Parameters } & \multirow{2}{*}{$\begin{array}{c}\text { Control } \\
\text { G1 }\end{array}$} & Diabetes +ve & Mucilage (fruits) & Protein (seeds) & Standard & \multirow{2}{*}{ ANOVA } \\
\hline & & G2 & G3 & G4 & G5 & \\
\hline \multirow{2}{*}{$\begin{array}{l}\text { Lipid peroxide } \\
\mathrm{nmol} / \mathrm{mg} \text { protein } \% \text { of } \\
\text { change }\end{array}$} & \multirow[t]{2}{*}{$25.63 \pm 1.83^{b}$} & \multirow{2}{*}{$\begin{array}{c}45.88 \pm 3.03^{\mathrm{a}} \\
+79\end{array}$} & \multirow{2}{*}{$\begin{array}{c}26.88 \pm 1.27^{\mathrm{b}} \\
\quad+4.87\end{array}$} & \multirow{2}{*}{$\begin{array}{l}32.41 \pm 2.03^{\mathrm{b}} \\
\quad+26.45\end{array}$} & $\begin{array}{c}28.17 \pm \\
1.99^{\mathrm{b}}\end{array}$ & \multirow[t]{2}{*}{0.0001} \\
\hline & & & & & +9.91 & \\
\hline \multirow[t]{2}{*}{$\begin{array}{l}\text { Catalase } U / \mathrm{mg} \text { protein } \\
\% \text { of change }\end{array}$} & \multirow[t]{2}{*}{$211.19 \pm 8.34^{\mathrm{a}}$} & \multirow[t]{2}{*}{$\begin{array}{c}144.12 \pm 11.14^{\mathrm{d}} \\
-31.76\end{array}$} & \multirow[t]{2}{*}{$\begin{array}{c}183.46 \pm 10.69^{\mathrm{bc}} \\
-13.13\end{array}$} & \multirow{2}{*}{$\begin{array}{c}171.07 \pm 12.49^{c} \\
-18.99\end{array}$} & $\begin{array}{c}189.64 \pm \\
6.26^{\mathrm{b}}\end{array}$ & \multirow[t]{2}{*}{0.0001} \\
\hline & & & & & -10.20 & \\
\hline \multirow{2}{*}{$\begin{array}{l}\text { GST U/mg protein } \\
\% \text { of change }\end{array}$} & \multirow[t]{2}{*}{$86.43 \pm 7.00^{\mathrm{a}}$} & \multirow{2}{*}{$\begin{array}{l}50.30 \pm 8.67^{\mathrm{c}} \\
\quad-41.81\end{array}$} & \multirow{2}{*}{$\begin{array}{c}72.68 \pm 8.47^{b} \\
-15.9\end{array}$} & \multirow{2}{*}{$\begin{array}{c}80.74 \pm 8.59^{\mathrm{ab}} \\
-6.58\end{array}$} & $\begin{array}{c}88.56 \\
\pm 6.19^{\mathrm{a}}\end{array}$ & \multirow[t]{2}{*}{0.0001} \\
\hline & & & & & +2.46 & \\
\hline
\end{tabular}

Data are means \pm SD of six rats in each group.

Data are expressed as $\mathrm{Ug} / \mathrm{mg}$ protein for glutathione and $\mathrm{nmol} / \mathrm{mg}$ protein for lipid peroxides.

Unshared letters between groups are the significance values at $p<0.05$.

Statistical analysis is carried out using one-way ANOVA using CoStat Computer Program.

membrane-bound enzymes and receptors cell membrane structure lose its continuity accelerating diabetes and other cellular damages like necrosis and inflammation which agreed with Ali et al. (2011), subsequently hypo-insulinemia led to an increase in the oxygenfree radicals, which could in-activate and reduce the catalase activity in the diabetic rats (Soon and Tan 2002). In addition to hepatic GSH reduction as result of increased ROS production and free radical scavenging activity inhibition agreed with Abd
El-Fattah et al. (2018) and Ahmed et al. (2015), as well as other hepatic metabolic disturbances reduction in albumin and total protein, GGT serum elevation, AST and ALT, and ALP elevation after STZ induction was in accordance with histopathological findings and indicator of liver damage and thus otherwise alterations in the hepatic functions (Ahmed et al., 2015).

Wang et al. (2016) suggested that both oral anti-diabetic drugs and insulin may lead to insulin resistance besides many 
Table 6. Effect of protein and mucilage of Casimiroa edulis seeds and fruits on blood serum albumin, GGT, and total protein in control and diabetic rats in comparison with glibenclamide.

\begin{tabular}{|c|c|c|c|c|c|c|}
\hline \multirow{2}{*}{ Parameters } & \multirow{2}{*}{ Control G1 } & Diabetes & Mucilage (fruits) & Protein (seeds) & Standard & \multirow{2}{*}{ ANOVA } \\
\hline & & G2 & G3 & G4 & G5 & \\
\hline $\begin{array}{l}\text { Albumin }(g / d l) \\
\% \text { of change }\end{array}$ & $10.19 \pm 1.58^{\mathrm{a}}$ & $\begin{array}{c}8.19 \pm 1.02^{\mathrm{b}} \\
-19.37\end{array}$ & $\begin{array}{c}9.22 \pm 0.72^{\mathrm{ab}} \\
-9.51\end{array}$ & $\begin{array}{c}9.82 \pm 0.99^{\mathrm{ab}} \\
-3.63\end{array}$ & $\begin{array}{c}9.30 \pm 0.94^{\mathrm{ab}} \\
-8.23\end{array}$ & 0.0122 \\
\hline $\begin{array}{l}\text { Total Protein }(\mathrm{g} / \mathrm{dl}) \\
\% \text { of change }\end{array}$ & $3.51 \pm 0.12^{\mathrm{a}}$ & $\begin{array}{c}2.16 \pm 0.10^{\mathrm{d}} \\
-38.46\end{array}$ & $\begin{array}{l}2.75 \pm 0.11^{\mathrm{c}} \\
\quad-21.64\end{array}$ & $\begin{array}{l}2.86 \pm 0.06^{\mathrm{c}} \\
\quad-18.51\end{array}$ & $\begin{array}{c}3.11 \pm 0.16^{\mathrm{b}} \\
-11.39\end{array}$ & 0.0001 \\
\hline $\begin{array}{l}\text { GGT }(\mathrm{g} / \mathrm{L}) \\
\% \text { of change }\end{array}$ & $22.31 \pm 3.16^{\mathrm{a}}$ & $\begin{array}{c}42.69 \pm 4.35^{\mathrm{d}} \\
+91.35\end{array}$ & $\begin{array}{c}33.13 \pm 3.17^{\mathrm{bc}} \\
+48.49\end{array}$ & $\begin{array}{c}36.78 \pm 3.68^{\mathrm{b}} \\
+64.86\end{array}$ & $\begin{array}{l}37.55 \pm 5.36^{\mathrm{b}} \\
\quad+68.31\end{array}$ & 0.0001 \\
\hline
\end{tabular}

Data are expressed as means \pm SD of six rats in each group.

Values of total protein are expressed as $\mathrm{g} / \mathrm{dl}$ and albumin are expressed as $\mathrm{g} / \mathrm{l}$.

$p$ is the level of significance, where $p<0.05$ is significant. ANOVA $p<0.0001$.

Statistical analysis is carried out using one-way ANOVA using CoStat Computer Program.

Table 7. Effect of protein and mucilage of Casimiroa edulis seeds and fruits on liver weight, body weight, and liver-body ratio in normal and diabetic rats in comparison with glibenclamide.

\begin{tabular}{|c|c|c|c|c|c|c|}
\hline \multirow{2}{*}{ Parameters } & \multirow{2}{*}{ Control G1 } & Diabetes & Mucilage (fruits) & Protein (seeds) & Standard & \multirow{2}{*}{ ANOVA } \\
\hline & & G2 & G3 & G5 & G7 & \\
\hline $\begin{array}{l}\text { Liver Weight } \\
\% \text { of change }\end{array}$ & $5.8 \pm 1.07^{\mathrm{bc}}$ & $\begin{array}{c}5.22 \pm 1.01^{\mathrm{c}} \\
-\mathbf{1 0}\end{array}$ & $\begin{array}{c}7.02 \pm 0.627^{\mathrm{ab}} \\
\quad+\mathbf{2 1 . 0 3}\end{array}$ & $\begin{array}{c}6.53 \pm 1.04^{\mathrm{abc}} \\
\quad+\mathbf{1 2 . 5 8}\end{array}$ & $\begin{array}{l}7.53 \pm 0.791^{\mathrm{a}} \\
\quad+\mathbf{2 9 . 8 2}\end{array}$ & $0.0018 * *$ \\
\hline $\begin{array}{l}\text { Body Weight } \\
\% \text { of change }\end{array}$ & $211 \pm 9.07^{\mathrm{b}}$ & $\begin{array}{c}173.17 \pm 9.1^{\mathrm{C}} \\
\mathbf{- 1 7 . 9 3}\end{array}$ & $\begin{array}{c}210 \pm 8.39^{b} \\
\mathbf{- 0 . 4 7}\end{array}$ & $\begin{array}{c}197.33 \pm 10.81^{b} \\
-6.48\end{array}$ & $\begin{array}{c}212 \pm 10.93^{b} \\
+\mathbf{0 . 4 7}\end{array}$ & 0.00001 \\
\hline $\begin{array}{l}\text { Liver/body/Weight. Ratio } \\
\% \text { of change }\end{array}$ & $0.028 \pm 0.005^{\mathrm{b}}$ & $\begin{array}{c}0.0299 \pm 0.004^{\mathrm{ab}} \\
+\mathbf{+ 6 . 7 9}\end{array}$ & $\begin{array}{c}0.034 \pm 0.002^{\mathrm{ab}} \\
\quad+\mathbf{2 1 . 4 3}\end{array}$ & $\begin{array}{c}0.0329 \pm 0.004^{\mathrm{ab}} \\
+\mathbf{1 7 . 5}\end{array}$ & $\begin{array}{c}0.036 \pm 0.0023^{\mathrm{a}} \\
\quad+\mathbf{2 8 . 5 7}\end{array}$ & $0.0056 * *$ \\
\hline
\end{tabular}

Data are means $\pm \mathrm{SD}$ of six rats in each group.

Data are expressed as weight in grams.

Unshared letters between groups are significance value at $p<0.05$.

Statistical analysis is carried out using one-way ANOVA by Co Stat Computer Program.

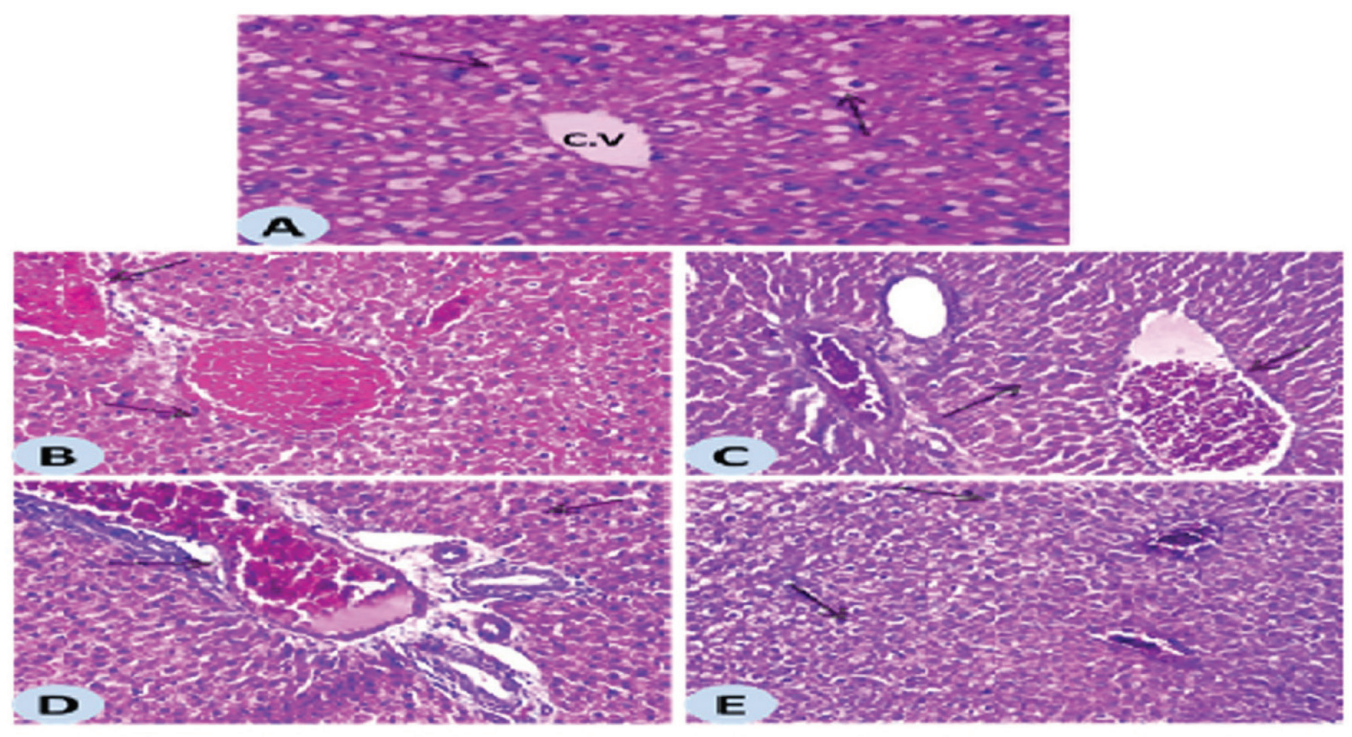

Figure 3. (A) A photomicrograph of rat hepatic tissue section showing normal histological structure of hepatic cells. (B) Severe dilatation congestion were detected in the central and portal veins as well as hepatic sinusoids in diabetic rats congestion in the central and portal veins were detected in group treated mucilage as in (C). (D) Some dilatation and congestion were observed in the central and portal veins in the portal veins in the portal area in group treated protein. [E] Showing nearly normal histological structure in group-treated glibenclamide. 


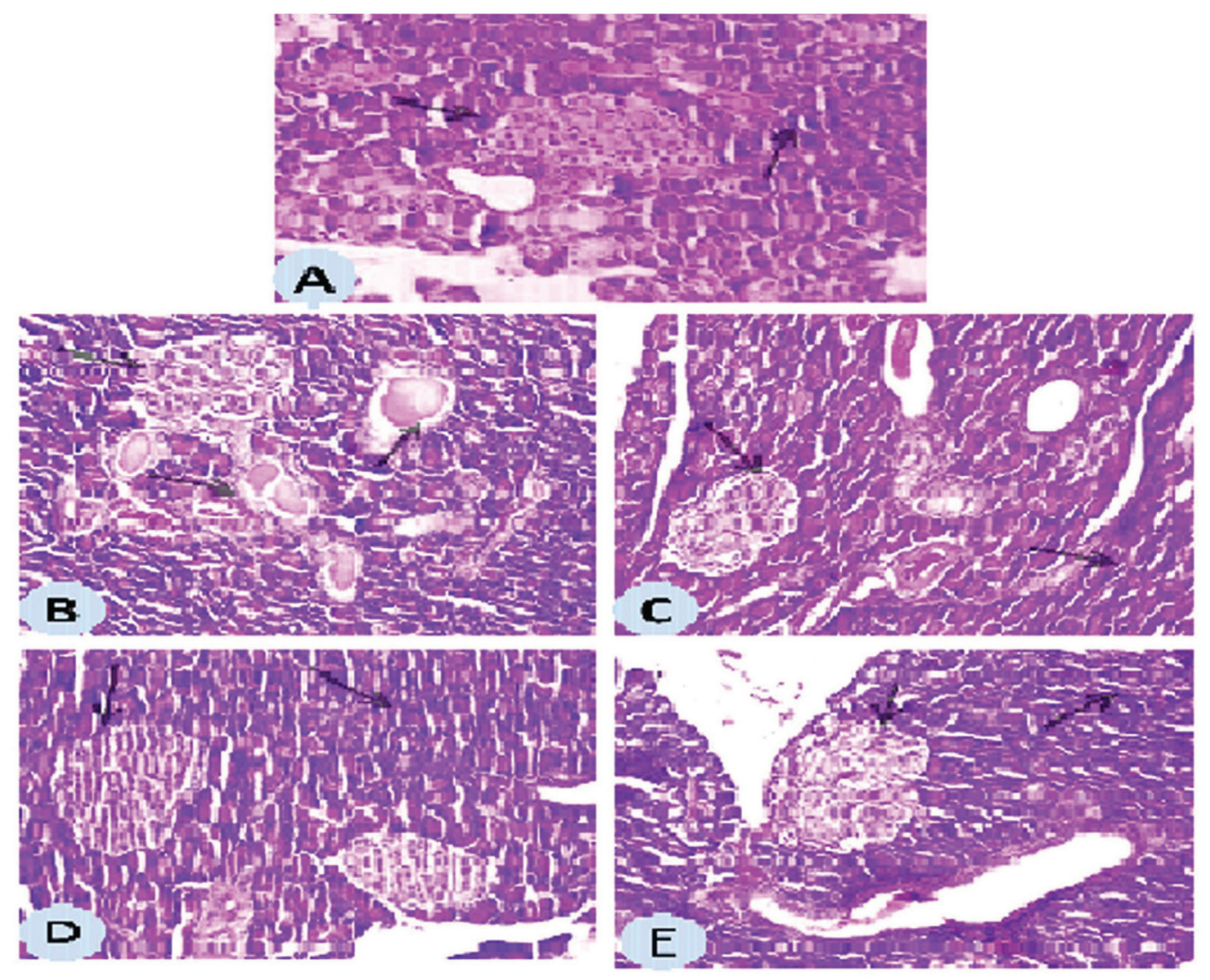

Figure 4. (A) A photomicrograph of rat pancreatic tissue section showing normal histological structure of islets of Langerhans cells as recorded in control group ( $H \& E \times 200)$. (B) The islets of Langerhans cells showed degeneration and atrophy as well as esoinophilic casts in the lumen of the pancreatic ducts in diabetic group. (C) Nearly normal histological structure in group treated mucilage. (D) Normal architecture of the pancreas as recorded in group treated protein. (E) Normal histological structure of islets of Langerhans cells in group treated with glibenclamide.

side effects, so we are looking for effective, non-toxic, and affordable drugs for diabetes. Protein and mucilage of $C$. edulis (Llave \& Lex) seeds and fruits have been prepared to be used as anti-hyperglycemic agents for the first time during this study, improving blood glucose level successfully after 3 to 4 weeks of treatment as well as improving other liver functions (ALP, AST, and ALT). Moreover, the antioxidant activity was studied, in which lipid peroxidation was remarkably decreased in protein and mucilage treated groups. A significant increase in the CAT activity of the diabetic rats treated with protein and mucilage was proved. Noticeable elevation of hepatic GSH level was observed in both the protein and mucilage treated diabetic rats agreed with previously mentioned by Ahmed et al. (2015). According to albumin content slight elevation was observed in groups treated with protein and mucilage. In the case of total protein results, there was significant amelioration in case of protein and mucilage, while GGT slight reduction in protein, mucilage treated groups with respect to control.

Hypoglycemic and antioxidant activities, as well as the recovery from other diabetic complications, may be attributed to presence of amino acids considered as the principal protein components, especially glutamic acid, the most prominent amino acid in C. edulis protein, in which it was previously proved by Reimann et al. (2004) that glutamine activate and potentiate GLP-
1 release, the principle metabolic gut fuel. The findings suggested that nutritional amino acid-like glutamine might have an effective role in obesity and diabetes.

Moreover Mansour et al. (2018) mentioned that glutamine as "essential" amino acid is the most human blood relevant element, playing a role as regulator of acid-base homeostasis and in gluconeogenesis and also a "nitrogen shuttle" between various organs, involved in as oxidizing agent for rapidly proliferating cells including enterocytes, reticulocytes, and immune cells. Also, glutamine has a signaling role in many processes including cell proliferation. Dietary intake of glutamine increased insulin circulation as explained above due to GLP-1 release.

Moreover, previous pharmacological studies proved that polysaccharides lowering blood glucose level by restoring pancreatic tissues roles and improving insulin output by beta cells ( $\beta$-cell), as well as increasing the sensitivity of insulin peripheral cells (Hu et al., 2013), also it was demonstrated previously that polysaccharides possess prominent efficacies on diabetes (Wang et al., 2016). Thus, the hypoglycemic activity may be attributed to the presence of polysaccharides and amino acids as major components of the fruits and seeds.

More investigations should be undertaken to identify more bioactive compounds of both hypoglycemic and antioxidant properties in Casimiroa edulis besides studying their mode of action. 


\section{CONCLUSION}

According to previous reported reviews, no study has up to the present date investigated the chemical compositions of protein and mucilage responsible for the hypoglycemic properties of $C$. edulis seeds and fruits, so this study for the first time focused on identifying the major amino acids and polysaccharides of the protein and mucilage accounted for the hypoglycemic activity of C. edulis as well as improving oxidative stress, liver functions, albumin, GGT, and total protein which is documented by the histopathological studies. Finally, further studies should be held to assure the beneficial effects of this plant for human being health and also its nutritional properties.

\section{ACKNOWLEDGMENTS}

Authors are grateful to Dr. Wael M. Aboulthana, Biochemistry Department, Genetic Engineering and Biotechnology Division, National Research Centre, Egypt, for his effective contribution in carrying out protein electrophoresis part.

\section{ABBREVIATIONS}

ALT: Alanine Aminotransferase

AST: Aspartate Aminotransferase

ALP: Alkaline Phosphatase

GGT: Gamma Glutamyl Transferase

CAT: Catalase

GSH: Glutathione

\section{CONFLICT OF INTEREST}

Authors declare that there are no conflicts of interest.

\section{FINANCIAL SUPPORT AND SPONORSHIP}

Authors are grateful to the National Research Centre, Egypt, for supplying the fund.

\section{ETHICAL APPROVAL}

Approvement of the anesthetic procedures complied with the legal ethical guidelines approved by both the Ethical Committee of the Federal Legislation and National Institutes of Health Guidelines in USA and the ethical committee of the National Research Centre in Egypt with registration No. (15-028).

\section{REFERENCES}

Abd El-Fattah AI, Ali SA, Aly HF, Abd-Alla HI, Shalaby NM, Saleh MH. Therapeutic potential of Achillea fragrantissima extracts in amelioration of high-fat diet and low dose streptozotocin diabetic rats. J Compl Med Res, 2018; 7:115-30.

Ahmed HH, Aly HF, Ali SA. Potential impact of COQ10 and vitamin $\mathrm{E}$ against (STZ) induced metabolic deterioration in the albino rats. Inter J Pharm Pharm Sci, 2015; 7:176-84.

Ali SA, Ibrahim, NA, Mohammed MMD, El-Hawary S, Refaat EA. The potential chemo preventive effect of ursolic acid isolated from Paulownia tomentosa, against N-diethylnitrosamine: initiated and promoted hepatocarcinogenesis. Heliyon, 2019; 5:e1769.

Ali SA, Hamed MA, El-Rigal SN, Shabana MH, Kassem MES. Chemical constituents of Argyreia speciosa Fam. Convolvulaceae and its role against hyperglycemia. J App Pharm Sci, 2011; 1: 76-84.

Aly HF, Rizk MA, Abo-Elmatty DM, Desoky MM, Ibrahim NA, Younis EA. Therapeutic and protective effects of Caesalpinia gilliesii and Cajanus cajan proteins against acetaminophen overdose-induced renal damage. Toxicol Ind Health, 2016; 32:753-68.
Awaad AS, Al-Japer NA, Soliman GA, Al-Outhman MR, Zain ME, Moses JE, El-Meligy RM. New biological activities of Casimiroa edulis leaf extract and isolated compounds. Phytoth Res, 2011; 26:452-7.

Darwesh OM, Moawad H, Barakat OS, Abd El-Rahim WM. Bioremediation of textile reactive blue azo dye residues using nanobiotechnology approaches. Res J Pharma Biol and Chem Sci, 2015; 6:1202-11.

El-Sayed AEB, Aboulthana WM, El-Feky AM, Ibrahim NE, Seif MM. Bio and phyto-chemical effect of Amphora coffeaeformis extract against hepatic injury induced by paracetamol in rats. Mol Biol Rep, 2018; 45:2007-23.

Hu J, Pang, W, Chen P, Bai sh, Zheng zh, Wu X. Hypoglycemic effect of polysaccharides with different molecular weight of Pseudostellaria heterophylla. BMC Complement Altern Med, 2013; 13:267-75.

Hyder MA, Hasan M, Mohieldein HA. Comparative levels of ALT, AST, ALP and GGT in liver associated diseases. Eur J Exp Biol, 2013; $3: 280-4$.

Ibrahim NA, Mohamed MMD, Aly HF, Ali SA, Abd Al-Hady D. Hypoglycemic effect of mucilage and methanol extract of Aegle marmelos (L.) Correa fruits in stereptozotocin diabetic rats. Der Pharma Chem, 2016; $8: 1-15$.

Landaverde NA, Juárez-Flores BI, Jiménez-Capdeville ME, Ortiz-Pérez MD. Anxiolytic and sedative effects of essential oil from Casimiroa pringlei on Wistar rats. J Med Plants Res, 2009; 3:791-8.

Mansour A, Hosseini S, Qorbani M, Larijani B, Reza M, Tehrani M. Amino acids levels related to glutamine supplementation for type 2 diabetes patients. Biomed Res, 2018; 29:2790-3.

Mohammed MMD, Ibrahim NA, Ali SA, Hamed MA, El-Rigal NS. Triacylglycerols of the seed oil of Linum grandiflorum Desf.: their composition, cytotoxicity, and hepatoprotective activity. Food Biochem, 2018; 42:1-13.

Reimann F, Williams L, Da Silva XavierG, Rutter GA, Gribble FM. Glutamine potently stimulates glucagon-like peptide- 1 secretion from GLUTag cells. Diabetologia, 2004; 47:1592-601.

Sadek SH A, Soliman AM, Marzouk M. Ameliorative effect of Allolobophora caliginosa extract on hepatotoxicity induced by silicon dioxide nanoparticles. Toxicol Ind Health, 2016; 32:1358-72.

Soon YY, Tan BKH. Evaluation of the hypoglycemic and antioxidant activities of Morinda officinalis in streptozotocin-induced diabetic rats. Singapore Med J, 2002; 43:77-85.

Taie HA, Abd-Alla HI, Ali SA, Aly HF. Chemical composition and biological activities of two Solanum tuberosum cultivars grown in Egypt. Intern J Pharm Pharm Sci, 2015; 7:311-20.

Uyar A, Yaman T, Keleș OF, Alkan EE, Celik I, Yener Z. Protective effects of Bryonia multiflora extract on pancreatic Beta cells, liver and kidney of streptozotocin-induced diabetic rats: histopathological and immunohistochemical investigations. Ind J Pharm Educ Res, 2017; 51:403-11.

Wang PC, Zhao S, Yang BY, Wang QH, Kuang HX. Antidiabetic polysaccharides from natural sources: a review. Carbohydr Polym, 2016; 148: 86-97.

Ya-Ming X, Ramirez-Ahumada MDC, Valeriote FA, Gunatilaka AAL. Solid tumor inhibitory and other constituents of Casimiroa tetrameria. Chin J Nat Med, 2011; 9:334-7.

How to cite this article:

Ibrahim N, Hawary SE, Mohammed M, Ali S, Kandil Z, Refaat E. Chemical compositions and hypoglycemic activities of the protein and mucilage of Casimiroa edulis (Llave \& Lex) seeds and fruits. J Appl Pharm Sci, 2019; 9(10):084-091. 